\begin{tabular}{l} 
RCCS \\
\hline Annual Review
\end{tabular}

\section{RCCS Annual Review}

A selection from the Portuguese journal Revista Crítica de Ciências Sociais

$2 \mid 2010$

Issue no. 2

\title{
Civil Society and Trade Negotiations: Constructing a New Field of Action in the Americas
}

\section{Marisa von Bülow}

Translator. Sheena Caldwell

\section{OpenEdition}

\section{Journals}

Electronic version

URL: http://journals.openedition.org/rccsar/233

DOI: $10.4000 /$ rccsar.233

ISSN: $1647-3175$

Publisher

Centro de Estudos Sociais da Universidade de Coimbra

\section{ELECTRONIC REFERENCE}

Marisa von Bülow, « Civil Society and Trade Negotiations: Constructing a New Field of Action in the Americas », RCCS Annual Review [Online], 2 | 2010, Online since 01 October 2010, connection on 01 May 2019. URL : http://journals.openedition.org/ rccsar/233 ; DOI : 10.4000/rccsar.233 


\section{Marisa von Bülow}

Instituto de Ciência Política, Universidade de Brasília

\section{Civil Society and Trade Negotiations: Constructing a New Field of Action in the Americas*}

This article analyses the process by which different civil society actors in the Americas have constructed a new field of collective action over the past twenty years. It focuses on attempts to establish new organisations on a domestic and transnational level, and thus helps provide a greater understanding of the dilemmas involved in the creation of new organisations which cross national borders. In particular, it analyses the case of the Hemispheric Social Alliance, an alliance of organisations and movements created in the mid-1990s. It argues that it is not possible to think of civil society coalitions in terms of a strict division between domestic and international levels. In addition, a view focussing exclusively on the role of states and international organisations is inadequate for understanding the increasingly complex dynamics of building up coalitions and forming preferences.

Keywords: transnationalism; civil society; trade; social networks; field of action.

\section{Introduction}

When new multilateral trade negotiations emerged in the public policy agenda in the 1990s, civil society actors in the Americas such as NGOs, trade unions and business organisations realised that they were not ready to face the challenges this presented. Firstly, there were few hemispheric or sub-regional spaces for the exchange of information and ideas. In addition, the key actors in trade discussions, such as some of the union federations, were not communicating with each other, due to the legacy of conflicts dating back to the Cold War era. There were precedents for transnational collaboration in the region, but the majority consisted of short-term measures and/or measures limited to expressions of solidarity resulting, for example, from violations of human rights during the military dictatorships in Latin America.

This article analyses the process by which different civil society actors in the Americas have constructed a new field for collective action over the past twenty years, solidifying and adapting old links whilst at the same time creating new transnational social networks around the issue of trade. More specifically, it focuses on attempts to institutionalise these links by creating new organisations on domestic and transnational levels. The article does not consider the actions of civil society as a whole, but only those of the actors that have taken a

\footnotetext{
* Article published in RCCS 86 (September 2009).
} 
critical or opposing stance to free trade agreements. ${ }^{1}$ It analyses, in particular, the case of the Hemispheric Social Alliance, an association of organisations and movements created in the mid-1990s.

The first part of the article discusses the creation of a new transnational field for collective action in the Americas, forged on the basis of trade negotiations which took place in the 1990s. It then analyses the process by which alliances were formed among civil society organisations, paying particular attention to the Hemispheric Social Alliance. The third and final part of the article offers a critical assessment of its coordinating structure at national and transnational level, focussing on the roles played by the mediators between these territorial levels.

The experience of the movements against trade negotiations in the Americas reveals that there are overlapping short-term initiatives organised around specific campaigns, and other initiatives that seek to provide a long-term response to the problems of coordination and representation within transnational collective action. On the basis of an analysis of the operations of the Hemispheric Social Alliance (HSA), it is argued that it is not possible to consider trade coalitions in terms of a rigid separation between domestic and international levels. It is also argued that a view which focuses exclusively on the role of states and international organisations is inadequate for understanding the increasingly complex dynamics of building up coalitions and forming preferences. This article therefore seeks to contribute towards a better understanding of how new and old forms of organisation relate to each other and the kind of tensions and obstacles that emerge from the different existing options.

\section{The construction of a new field for collective action}

From the 1990s onwards, trade negotiations have become important arenas for debates on the future of globalisation and global governance and have included the presence of a growing number of non-state actors. It is enough to recall the protests that took place during the World Trade Organisation (WTO) ministerial meeting in Seattle in 1999. However, it is only possible to understand what took place in Seattle by taking the politicisation of trade

\footnotetext{
${ }^{1}$ It is important to clarify that the actors included in this work do not see themselves as against trade or even the liberalisation of trade. Their positions vary, ranging from those who want to reform the agreements to those who think that this is not possible; they also vary according to what is being debated and the specific subject being negotiated.
} 
negotiations in the Americas during the previous decade into account. The North American Free Trade Agreement (NAFTA) negotiated between the United States, Canada and Mexico between 1991 and 1993 is the most appropriate historical reference from which to begin to understand the important changes that took place, not only in the agenda for agreements, but also in the way in which many civil society organisations began to react to those debates. $^{2}$

In fact, the NAFTA inaugurated a new generation of free trade agreements in which issues such as intellectual property, investment rules and, to a lesser extent, labour rights and protection of the environment became almost as important as issues relating to market access. $^{3}$ In addition, for the first time a broad range of civil society organisations (CSOs) actively took part in the debates on the agreement, divided in each country and across national borders between groups that supported or opposed the negotiations. New organisations and alliances had to be created to monitor the trade negotiations and assess their impact, whilst already existing organisations incorporated the subject into their agendas.

However, it was the negotiations for the Free Trade Area of the Americas (FTAA), launched in 1995, that led a broad and heterogeneous group of civil society organisations from all of the Americas to meet to find common platforms for collective action. The creation of the Hemispheric Social Alliance (HSA) during the FTAA ministerial meeting in Belo Horizonte in 1997 was the main attempt to create a coordinating structure for these groups of actors at hemispheric level.

The main criticisms presented by the actors were related to the lack of transparency in negotiation procedures, the lack of channels for dialogue with civil society organisations, the absence of social and environmental themes from the agenda, the unequal distribution of the benefits and costs of agreements, the threat presented by agreements to the sovereignty of countries and the ability of states to implement public policies, and the risk of a "race to the bottom" or, in other words, the tendency for countries to compete against each other on

\footnotetext{
${ }^{2}$ The agreement negotiated between Canada and the United States (the Canada-U.S. Free Trade Agreement CUSFTA), which came into force in 1989, was an important predecessor to the NAFTA.

${ }^{3}$ The proliferation of NAFTA-style regional agreements was not restricted to the Americas. Practically all members of the WTO became part of preferential agreements (see http://www. wto.org/english/tratop_e/region_e/region_e.htm). This process occurred in parallel with global negotiations, creating, in practice, a complicated and asymmetrical system of global governance of trade which critics have called the "spaghetti bowl" phenomenon (the term was first used in Bhagwati, 1995).
} 
the basis of increasingly lower salaries and less efficient environmental and labour legislation.

The building up of links between CSOs critical of trade negotiations throughout the 1990s makes it possible to speak of the creation of a new field for collective transnational action, defined as a space for political action made up of individuals and civil society organisations involved in the process of producing a common set of practices, objectives and beliefs. ${ }^{4}$ Its main characteristics are: a) its simultaneous presence at both domestic and transnational levels; b) its dynamism, both in the sense that its constituent practices and beliefs are questioned or reaffirmed on an ongoing basis, and the fact that the number of participants has varied over time; c) its connection and articulation with other spaces for domestic and transnational collective action; d) its internal heterogeneity and asymmetry, being composed of civil society organisations whose roles, interests and power vary greatly; and, finally, e) the plurality of trajectories employed to reach beyond national borders in terms of alliancebuilding policy, forms of organisation and ideas.

Within this context, the attention traditionally paid to the role of states and international organisations has become inadequate for understanding the new dynamics of the creation of alliances and the formation of preferences. Most civil society organisations included in this study are involved in other networks and fields that often have little to do with the debates on access to markets, but have become interested in trade agreements due to the expansion of the negotiation agenda during the 1990s. In addition to the different themes pursued by CSOs within the field of collective action, there is also a significant diversity in terms of their objectives and strategies. The majority of these organisations have their roots in national spaces and prioritise domestic changes, whilst at the same time constructing transnational alliances. Due to this diversity, this article refers to multiple trajectories for transnationality or, in other words, the multiple ways in which civil society organisations participate in debates, actions and processes that lead them beyond national borders without necessarily renouncing activities on a domestic level (von Bülow, 2009 and 2010).

\footnotetext{
${ }^{4}$ The definition proposed in this article emphasises the political dimension of the creation of a field and also a more dynamic vision than the more institutionalised definitions proposed in the literature on organisations. In this sense, it is similar to the notion of "network domains" proposed by White and Mische, which are defined as "specialized fields of interaction characterized by clusters of relations and associated sets of stories" (see Mische, 2003: 264; and Mische and White, 1998).
} 
The choice of these paths or trajectories is influenced by the previous identities of the organisations (their agendas, objectives and alliances) and by changes in the structure of political opportunities (for example, the launch of new trade negotiations), but is also the result of a dynamic process of interaction with other actors. This process is characterised by the lack of a clear consensus on the validity of previous repertoires and, more specifically, on how transnational alliances should be institutionalised, which demands should be given priority and what the demands should target.

\section{The institutionalisation of links}

In 1986, a trade union federation such as the North American AFL-CIO (American Federation of Labor-Congress of Industrial Organizations) would discuss strategies related to trade negotiations on a domestic level and, to a lesser extent, with its peers in the international trade union forums in which it was involved. Twenty years later, the same organisation discusses its positions in a number of arenas at the same time: within the context of the Hemispheric Social Alliance (HSA), the Hemispheric Campaign against the FTAA, the Stop CAFTA Coalition (a North American alliance against the free trade agreement between Central America and the United States), the Alliance for Responsible Trade (the national chapter of the HSA) and the forums of the trade union movement, amongst others. The same may be said of many NGOs concerned with human rights or gender issues, which have also begun to participate in alliances created around trade discussions, whilst at the same time remaining involved in other initiatives that are related to their own specific themes. This great plurality is something new and is the result of dissatisfaction with forms of organisation based on rigid rules that exclude participation, which characterised a great deal of transnational collective action in the past.

However, this dissatisfaction goes hand-in-hand with the absence of a model acceptable to all and the risk of growing organisational fragmentation. Multiple responses to the organisational problems of transnational collective action are possible in specific circumstances and are subject to renegotiation. The objective of the actors studied has been to generate spaces for dialogue that will help coordinate collective action without replacing or excluding already existing organisations. 


\subsection{Between campaigns and alliances}

The formation and institutionalisation of links between actors has not been a linear, ongoing process in which the coalitions created and strengthened at domestic level would later spill over into the transnational arena (see chronology, Figure 1). On the contrary, it has been a more chaotic process involving the institutionalisation of links on both levels at the same time. In all cases, however, these initiatives have had to face the challenge of sustainability and some have not survived.

The new coalitions dedicated to the subject of trade coexist with a variety of other alliances that flourished during the same period, or already existed. ${ }^{5}$ The objective has not been to replace these other initiatives or even to compete with them, but to create intersecting spaces to coordinate collective action specifically related to negotiations for free trade agreements. As one individual involved in these efforts explained, there was a general agreement on the need to define rules for coexistence that would enable effective and plural actions to take place:

We had this criticism in common, which is related to the construction of a new subject, that we had to work efficiently, linking international affairs with local impacts but without these false, newfangled notions of big conglomerates and representations, which are often fictitious. ${ }^{6}$

However, as previously stated, there was no established, agreed organisational model. The variety of types of coalitions that were created reflects the actors' different views on how collective transnational action should be organised, the role they should play and the desired alliances. More specifically, these responses vary between those which place greater emphasis on autonomy and horizontality in relations between members - the typical model for coalitions created to coordinate transnational campaigns - and more ambitious projects to create alliances based on explicit rules for affiliation and representation.

\footnotetext{
5 In their research into regional Latin American organisations (which they call "regional networks"), Korzeniewicz and Smith identified almost three hundred. The number would be even higher if the authors had taken the entire hemisphere into consideration (see Korzeniewicz and Smith 2003a: 13).

${ }^{6}$ Interview with Coral Pey, Executive Director, Alianza Chilena por un Comercio Justo y Responsable (ACJR), Santiago de Chile, June 2005.
} 
FIGURE 1 - CHRONOLOGY FOR THE CREATION OF TRADE COALITIONS IN THE AMERICAS

\begin{tabular}{|c|c|c|}
\hline DOMESTIC LEVEL & $\begin{array}{l}\text { YEAR } \\
1986 \rightarrow\end{array}$ & $\begin{array}{l}\text { TRANSNATIONAL LEVEL } \\
\text { Creation of Coordenadora de Centrais Sindicais } \\
\text { do Cone Sul (CCSCS) }\end{array}$ \\
\hline $\begin{array}{l}\text { Creation of the Pro-Canada Network, later } \\
\text { renamed Action Canada Network (ACN) }\end{array}$ & $\leftarrow 1987$ & \\
\hline Creation of Common Frontiers, Canada & $\leftarrow 1988$ & \\
\hline $\begin{array}{l}\text { Creation of Red Mexicana de Acción frente al } \\
\text { Libre Comercio (RMALC), the Quebec Coalition } \\
\text { on Trilateral Negotiations, renamed the } \\
\text { Quebec Network on Continental Integration } \\
\text { (RQIC), and Mobilization on Development, } \\
\text { Trade, Labor and the Environment, renamed } \\
\text { the Alliance for Responsible Trade (ART/USA) }\end{array}$ & $\leftarrow 1991$ & \\
\hline $\begin{array}{r}\text { Creation of Citizens' Trade Campaign } \\
\text { (CTC/USA) }\end{array}$ & $\leftarrow 1992$ & \\
\hline \multirow{2}{*}{$\begin{array}{r}\text { Creation of Red Chilena por la Integración de } \\
\text { los Pueblos (Rechip), renamed Alianza Chilena } \\
\text { por un Comercio Justo y Responsable (ACJR) }\end{array}$} & $\leftarrow 1994$ & \\
\hline & $1997 \rightarrow$ & $\begin{array}{l}\text { Idea to create Hemispheric Social Alliance (HSA) } \\
\text { launched during ministerial meeting of FTAA }\end{array}$ \\
\hline \multirow[t]{3}{*}{$\begin{array}{r}\text { Creation of Rede Brasileira pela integração } \\
\text { dos Povos (REBRIP), Brazil }\end{array}$} & $\leftarrow 1998$ & \\
\hline & $1999 \rightarrow$ & $\begin{array}{l}\text { Launch of International Gender and Trade } \\
\text { Network (IGTN) }\end{array}$ \\
\hline & $2001 \rightarrow$ & Launch of Stop CAFTA Campaign \\
\hline $\begin{array}{r}\text { Creation of national chapters of the } \\
\text { Hemispheric Campaign against the FTAA in } \\
\text { Argentina, Brazil, Mexico, Bolivia, Colombia, } \\
\text { Ecuador, Uruguay and other countries }\end{array}$ & $\leftarrow 2002 \rightarrow$ & Launch of Hemispheric Campaign against the FTAA \\
\hline
\end{tabular}


In fact, civil society actors involved in transnational coalitions are confronted with a basic dilemma, caught between the need to guarantee the continuity and efficiency of collective action by creating rules (and asymmetries) and the pressure to maintain horizontal relations that ensure respect for autonomy and equality amongst participants. It is clear, however, that this is not a new dilemma, ${ }^{7}$ but rather one that has acquired new outlines in the broader context of transnational collective action.

In literature on the creation of transnational coalitions it has become common to use the term "networks" to describe the supposed trend towards the creation of more horizontal and flexible forms of organisation. ${ }^{8}$ The use of this term is based on the distinction proposed by Powell between network, market and hierarchy (Powell, 1990). According to this concept, networks are different from hierarchies because they are more horizontal, have no centre or chain of command, and are therefore more flexible and adaptable than hierarchical organisations. This use of the term is similar to the use made by civil society actors themselves, who refer to many coalitions as "networks" as a means of emphasising their horizontality, flexibility and internal democracy. "Networks" are therefore seen as providing "a superior social morphology for all human action" (Castells, 2000: 15).

This article does not employ the notion of networks as superior forms of organisation, for theoretical and methodological reasons. The metaphorical and organisational use of the term only confuses the debate, either because the concept is not clearly defined or because it establishes an a priori superiority for the absence of hierarchies and diverts our attention from the power relations, asymmetries and conflicts amongst actors. ${ }^{9}$ As used in this article, the term "networks" refers to the tradition of analysing social networks developed in the social sciences several decades ago. ${ }^{10}$ In this tradition, social networks are defined as standardised links between actors (individuals, organisations or even countries); they are, at the same time, bases for collective action - which is only made possible due to the interaction between actors - and results of collective action, on the basis of which new links

\footnotetext{
${ }^{7}$ For an interesting review of these debates which goes back to $19^{\text {th }}$ century feminism, see Clemens 2005.

${ }^{8}$ See, for example, the definition of networks as "forms of organization characterized by voluntary, reciprocal, and horizontal patterns of communication and exchange" (Keck and Sikkink, 1998: 8), and the distinction between networks, coalitions and movements proposed by J. Fox, in which "networks" are the organisations with the weakest links between participants (Fox, 2002).

${ }^{9}$ More generally, this criticism has been directed towards a trend in the sociology of organisations that views flexible organisations that are capable of continually redefining their results and internal structures positively, ignoring the tensions between actors. See, for example, the analysis by Melucci (1996), in particular p. 251.

${ }^{10}$ For a historical overview of the development of network analysis as a field of study, see Freeman, 2004.
} 
are created. Whether the links between actors are horizontal or vertical is a question that can only be answered through empirical research.

The efforts of actors to create new forms of organisation on a domestic and transnational level are part of a still unresolved tension between coordination and representation structures that are, to a greater or lesser extent, hierarchical. The Hemispheric Social Alliance (HSA) is a good example of a model that aims to be horizontal.

\subsection{The Hemispheric Social Alliance}

The case of the Hemispheric Social Alliance (HSA) is particularly interesting as it is an innovation in terms of the creation of transnational organisations. The Alliance is composed of eighteen "national chapters" and fifteen "regional members" (see Figure 2). Its members seek long-term collaboration between existing and new organisations by creating rules for coordination and representation based on the principle of consensus in decision-making.

Since its creation, the HSA has passed through four phases. The first, between the launch of the proposal to create a hemispheric alliance in 1997 in Belo Horizonte and the first meeting of the Coordinating Committee in March 1999, was the initial discussion phase determining how the HSA should operate and the systematisation of the main demands to be presented to national governments (mainly relating to the FTAA negotiations). The consolidation phase took place between 1999 and January 2002, ending with the decision to launch the Hemispheric Campaign against the FTAA. ${ }^{11}$ Between 2002 and the ministerial meeting in Miami at the end of 2003, the FTAA remained the main topic on the agenda and the national chapters were mobilised in conjunction with the Hemispheric Campaign. Finally, from the beginning of 2004, the Alliance entered into a new phase, increasingly expanding its agenda to include global trade negotiations and other regional agreements, and linking the subject of trade to other issues such as negotiation of the external debt and militarisation.

\footnotetext{
${ }^{11}$ Before the 2001 Quebec Summit, HSA documents contained lists of demands mainly relating to the need to obtain greater access to the negotiation process. During the Summit, the HSA launched its new slogan: "The HSA says NO to the FTAA; other Americas are possible" (see Korzeniewicz and Smith 2003b: 67).
} 
FIGURE 2 - MEMBERS OF THE HSA HEMISPHERIC COUNCIL

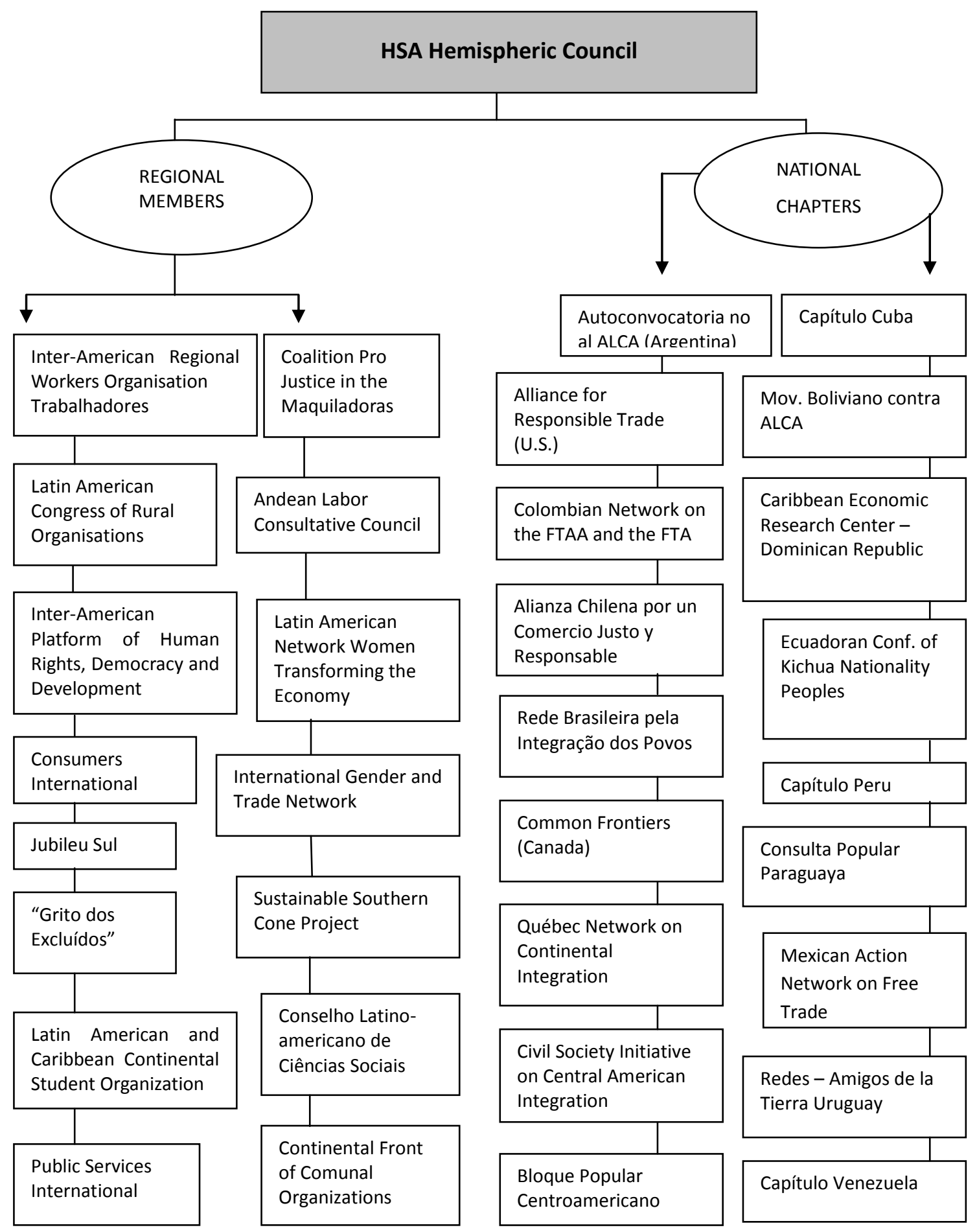


The HSA does not include all civil society organisations, even though it has been able to involve some of the most important actors in the field of collective action critical of trade negotiations. ${ }^{12}$ The majority of its members lie between the centre and the left of the political and ideological spectrum, united by a negative assessment of the consequences of free trade agreements. The hemispheric - rather than Latin American - nature of the HSA is, in itself, an innovation in terms of transnational relations in the region, as one of those involved argued:

There has been a break with the Latin American view that alliances cannot be made with movements in the North and this is very important, it is one contribution the Hemispheric Social Alliance has made ... we are living in a different age now, it is no longer "the ones in the South fighting and the ones in the North sympathising." The struggle involves both sides now. ${ }^{13}$

Although there are various examples of collaboration in the past between its members, the HSA is innovative in terms of its plural organisation, aiming to be a sustainable alliance based on common principles and objectives. In terms of rules for affiliation, the HSA incorporates organisations and other coalitions through their involvement either in the HSA national chapters or in regional organisations, most of which already existed before the Alliance was created (see Figure 2). It is precisely because the HSA has managed to include organisations from various sectors and because it acts as a bridge between North and South that this experience has been considered in literature on the subject as an example of the "possibility of broader alliances built around the larger issue of democratising economic governance" (Anner and Evans, 2004: 40). There are, however, many challenges and ambiguities in the functioning of the HSA that threaten its sustainability.

The HSA is defined by its members as an "open space," a "forum [...] created in order to exchange information, define strategies and promote common actions, with the aim of finding an alternative and democratic development model." ${ }^{14}$ The Alliance does not charge its members, but supports itself through funding from foundations and NGOs, which is used to pay for the operations of a lean organisational structure and some publications. ${ }^{15}$ The

\footnotetext{
${ }^{12}$ Organisations which participate in the Hemispheric Campaign against the FTAA but are not members of the HSA are important exceptions. They include Public Citizen, in the USA, ecumenical Brazilian organisations and also conservative organisations that criticise trade negotiations from a different ideological perspective.

${ }^{13}$ Interview with Héctor de la Cueva, Director, Centro de Investigación Laboral y Asesoría Sindical (CILAS), Mexico City, August 2004.

${ }^{14}$ See http://www.asc-hsa.org, accessed on 1 March 2006.

${ }^{15}$ For example, the publication of various versions of the document "Alternatives for the Americas" in Spanish, Portuguese and English has been financed by the John D. and Catherine T. MacArthur Foundation, the
} 
Alliance has no actual offices, but a rotating secretariat, a coordinating committee and a Hemispheric Council which meets regularly (see Figure 2). ${ }^{16}$ It does not see itself as "an organisation with structures and hierarchies of any kind, but rather as a process under construction."17

Despite this emphasis on horizontality and consensus, the HSA cannot be considered a space open to all who want to participate. Its dual affiliation rule creates greater flexibility than other organisations (such as the international trade union movement), but even so the rules separate those who can become members and those who cannot. For example, individuals and isolated organisations cannot become members. Those who do not belong to regional organisations and/or do not want to become part of the national HSA chapters are automatically ruled out. In fact, a significant part of the field of collective action remains outside the HSA. $^{18}$

Since its foundation, members of the Alliance have made a conscious effort to even out internal power imbalances. However, in the initial phase the "NAFTA 'Veterans'", as Foster calls the main participants in the Mexico, United States and Canada national chapters, were at the centre of HSA activities and decisions (Foster, 2005: 221). Partly due to this, the Alliance has been criticised for not being "as hemispheric as its name suggests" (Massicotte, 2003: 121). Efforts to include more members from the South have led, however, to a certain distancing of the U.S. and Canadian organisations. Spanish has become the de facto language of the HSA. This is a problem mainly for English and French-speaking participants and indigenous organisations. ${ }^{19}$ Whilst some organisations from North American civil society have employed staff fluent in Spanish or Portuguese, many others have not done so and this has effectively limited their participation in meetings and telephone conferences, as one HSA representative claims: "[A]II the HSA meetings are held in Spanish, so those who do not speak the language cannot even think about taking part." ${ }^{20}$ In practice the result is a certain

\footnotetext{
Rockefeller Foundation and the Solidago Foundation.

${ }^{16}$ Initially, the intention was to create a more complex organisation with theme groups at hemispheric level, but only two became active: the group which monitors FTAA negotiations and the Gender Committee. Interview with Gonzalo Berrón, HSA Secretariat, São Paulo, April 2005.

${ }^{17}$ See http://www.asc-hsa.org, accessed on 1 March 2006.

${ }^{18} 55$ (almost 45\%) of the 123 CSOs interviewed in Brazil, Chile, Mexico and the USA were not involved in the HSA at the time when they answered the questionnaire. Although this is not a representative sample, it indicates that an important part of the critics of trade agreements remains outside the HSA.

${ }^{19}$ For example, Canadian participants have raised the problem of the exclusion of indigenous peoples due to language problems (see Koo, 2001: 58).

${ }^{20}$ Interview with Karen Hansen-Kuhn, ART Secretary, Washington D.C., September 2005.
} 
tendency for the same individuals, those with language skills and/or members of organisations with more resources, to be the ones who always participate in meetings and telephone conferences.

The idea of creating national chapters of the Alliance, which would serve as broad spaces on a domestic level to mobilise organisations around trade actions, could mitigate the tendency towards the concentration of links at transnational level. However, the national chapters of the Hemispheric Social Alliance tend to be caught up in a vicious circle: declining and irregular participation leads to activities and decision-making processes being concentrated in an increasingly smaller group of individuals and to their legitimacy being questioned when they exercise coordination and representation functions, both on a domestic level and in international contexts (von Bülow, 2010). This, in turn, leads to greater disenchantment with the organisation and even less participation. This vicious circle is not the only challenge faced by the national chapters of the HSA, but it is even more difficult to transform it into a virtuous circle when it involves collective action on different geographical scales. In the four countries studied, different responses emerged to this shared challenge.

\section{The importance of missing links}

Each and every effort to institutionalise transnational links has to offer responses to the challenges of coordination and representation on different territorial scales. Despite aiming to create open spaces with little hierarchy, in at least four of the main countries in the Americas - Brazil, Chile, Mexico and the United States - the process of forming HSA chapters has faced criticism from those who do not feel represented.

More specifically, links between organisations in the capitals or major urban centres and organisations in the interior are lacking. In the case of the U.S., for example, organisations outside the "Beltway" (the motorway which encircles the capital, Washington, D.C.) criticise organisations such as the trade union federation AFL-CIO and the NGO Public Citizen for devoting an excessive amount of their time to lobbying, and for concentrating resources in their hands. However, this problem is not specific to U.S. organisations. In other countries local CSOs also complain about the lack of access to decision-making processes concerning strategies to be adopted and the unequal distribution of financial resources. ${ }^{21}$ Indeed, the

\footnotetext{
${ }^{21}$ These complaints emerged in the interviews with various civil society actors in Mexico. For an analysis of the same problem amongst organisations in Argentina, see Herkenrath, 2006.
} 
majority of meetings at which these decisions are made are held in the capitals of countries and/or in major urban centres.

In addition, some types of organisations have become less visible in the field of collective action in recent years. Opposition to the FTAA, which has been defended by the Hemispheric Social Alliance since 2001, is not consensual amongst all the organisations critical of the trade policies implemented in the hemisphere. The radicalisation of political positions has, in practice, marginalised the more reformist actors who are not against trade agreements but would like to change the agenda for negotiations and the contents of some proposals.

Finally, despite the existence of a general trend towards the creation of more intersectoral ties, there is a great variety in terms of the broadness of these alliances, and therefore in the ability and willingness of organisations to enter into dialogue and collaborate with partners outside their specific context. For example, in the case of the trade union federations affiliated to the Organização Regional Inter-americana de Trabalhadores (ORIT Inter-American Regional Workers' Organisation), some members have stood out for supporting "social alliances" with other social movements and NGOs, yet there is still internal resistance and these alliances are not implemented with the same enthusiasm by all members in all countries (von Bülow, 2009).

Actors interviewed in Brazil, Chile, Mexico and the United States acknowledged the difficulties they face in terms of the national chapters of the HSA (see Table 1) providing for the effective and ongoing participation of all interested parties. In part, these difficulties are related to the challenge of aiming to create permanent organisations to deal with a theme that features intermittently on the agenda of most participants. Thus, periods of peak mobilisation are followed by a rapid decline in attention to the issue by CSOs and public opinion in general.

\subsection{The ability of domestic coalitions to act as mediators}

The creation of domestic coalitions on trade in the Americas is an interesting example of the transnational diffusion of an organisational formula that seeks to offer a response to the problems of coordination, representation and knowledge production. The coalitions created at the beginning of the 1990s in the United States and Mexico to discuss the NAFTA were based on the experience of the Action Canada Network, previously created to attempt to influence trade negotiations between the United States and Canada (see Table 1). These 
coalitions, in turn, influenced the creation of similar ones in South America. Thus, when the decision was made to establish an HSA chapter in Brazil in the late 1990s, the aim of those involved was to create "a Brazilian RMALC (Red Mexicana de Acción Frente al Libre Comercio)". ${ }^{22}$

TABLE 1 - HSA NATIONAL CHAPTERS IN BRAZIL, CHILE, MEXICO AND THE UNITED STATES

\begin{tabular}{|c|c|c|c|}
\hline Country & HSA Chapter & Year founded & Number of members * \\
\hline Brazil & REBRIP - Rede Brasileira pela Integração dos Povos & 1999 & 38 \\
\hline Chile & $\begin{array}{l}\text { ACJR - Alianza Chilena por un Comercio } \\
\text { Justo y Responsible }\end{array}$ & 1995 & $\begin{array}{l}\text { Has not been an SCO } \\
\text { alliance since } 2004\end{array}$ \\
\hline México & $\begin{array}{l}\text { RMALC - Red Mexicana de Acción frente al Libre } \\
\text { Comercio }\end{array}$ & 1991 & 16 \\
\hline United States & ART - Alliance for Responsible Trade & 1991 & 32 \\
\hline
\end{tabular}

Sources: Interviews and web pages of organisations: www.art-us.org; www.rmalc.org.mx; www.rebrip.org.br; www.comerciojusto.cl.

* Approximate numbers based on estimates provided by the organisations themselves in 2006; the number of members varies over time.

These coalitions were established with very specific objectives: to coordinate collective action on trade; to serve as political spaces for interaction between the different ideological and sectoral arenas; to translate the technical language of the trade agreements for civil society actors; to produce analyses of the possible impacts of agreements and alternatives; and to mediate between local, national and international levels of action. However, absent links restrict this capacity to mediate. Research carried out in 2004 and 2005 into 123 civil society organisations involved in mobilisations critical of trade agreements in the four countries showed a tendency for increasingly fewer organisations to base their support exclusively on domestic coalitions when planning collective action on this issue. Although this is not a representative sample, it does include the main actors in each country (see Appendix I for a list of the organisations). With the aim of assessing the ability of the national coalitions to act as mediators, one of the questions put to members of these organisations was the following: if you wanted to take part in events parallel to an FTAA ministerial

\footnotetext{
${ }^{22}$ Interview with Fátima Mello, REBRIP Secretariat, Rio de Janeiro, May 2005.
} 
meeting taking place in another country, how would you make contact with possible partners in that country ${ }^{23}$

In the case of Mexico, when asked how they would make contact with organisations in the United States in the event of a meeting taking place in that country, almost half of the 29 organisations included in the research study said that they would do so through the national chapter of the Hemispheric Social Alliance, the RMALC (Mexican Action Network on Free Trade). However, only one said that this would be the only channel for mediation. The majority would also make direct contact and/or use other mediators such as the HSA secretariat, regional sector organisations and other Mexican organisations (see Chart 1).

\section{CHART 1 - TRAJECTORIES USED BY MEXICAN ORGANISATIONS TO MAKE CONTACT WITH PARTNERS IN THE UNITED STATES}

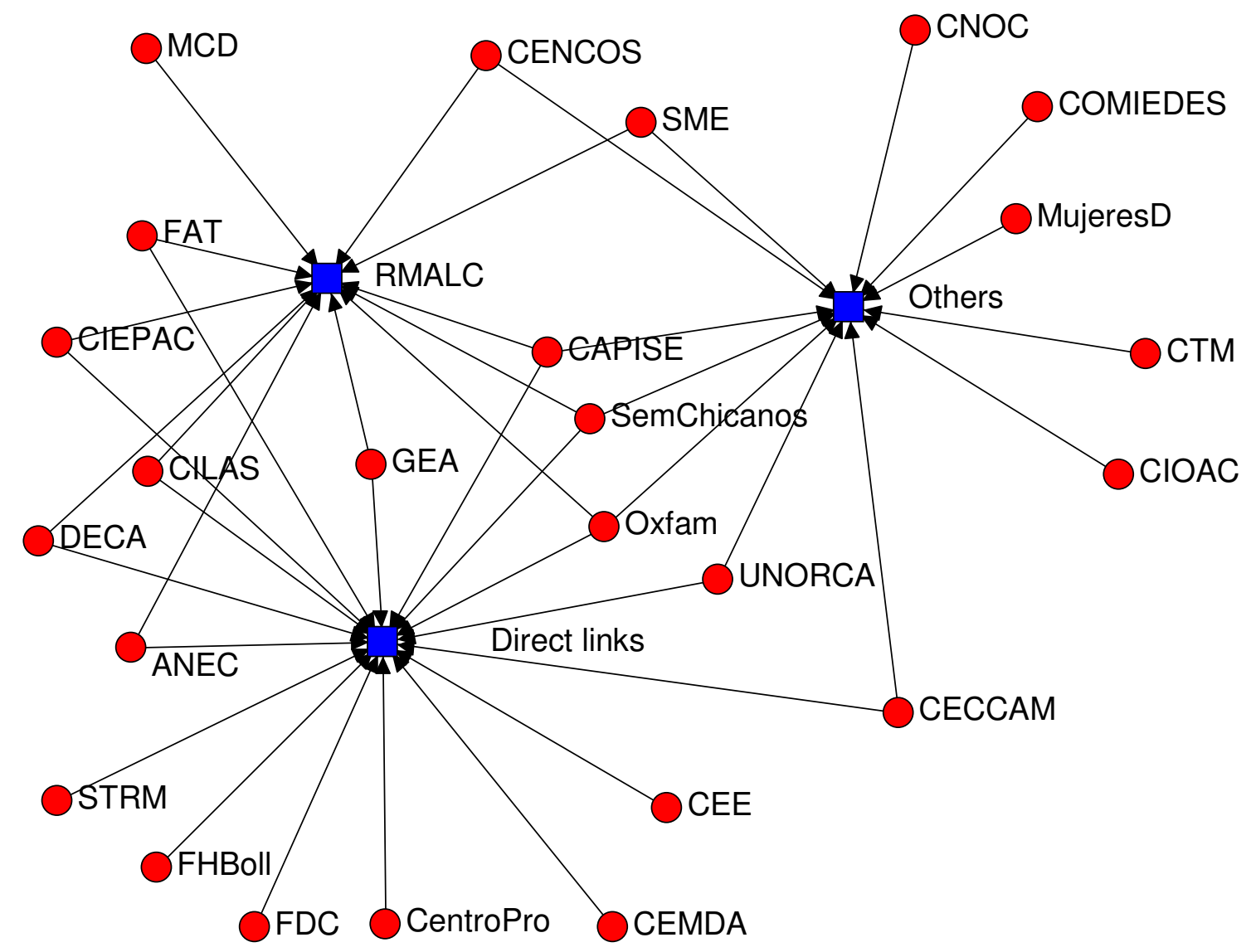

- Civil Society Organisations $\square$ Trajectories

Source: Interviews with members of civil society organisations (see Appendix I).

\footnotetext{
${ }^{23}$ The questionnaire phrased it thus: "Suppose for a moment that the next FTAA ministerial meeting is to be held in Brazil, Mexico, Chile or the United States and you need to discuss a participation strategy with organisations in that country. Would your organisation make direct contact with the organisations in the country? If so, would you make contact: through the national coalitions; through other national organisations; through regional networks such as the Hemispheric Social Alliance; not make contact; don't know."
} 
As a member of the RMALC explained, in recent years there has been a tendency for links between organisations in Mexico and other countries to multiply, accompanied by less dependence on the RMALC as the only mediator capable of achieving international alliances:

The RMALC has contacts and considerable significance on an international level but it does not really serve as a bridge between national and global levels. They [RMALC leaders] make contacts but the information has not been shared... We are starting to make our own links... ${ }^{24}$

When the same question was put to civil society organisations in Chile, the majority replied that they would not make contact with organisations in the U.S. via the HSA national chapter, the ACJR, nor would they do so directly, but would use other mediators, mainly the regional sector organisations or other Chilean organisations (see Chart 2).

\section{CHART 2 - TRAJECTORIES USED BY CHILEAN ORGANISATIONS TO MAKE CONTACT WITH PARTNERS IN THE UNITED STATES}

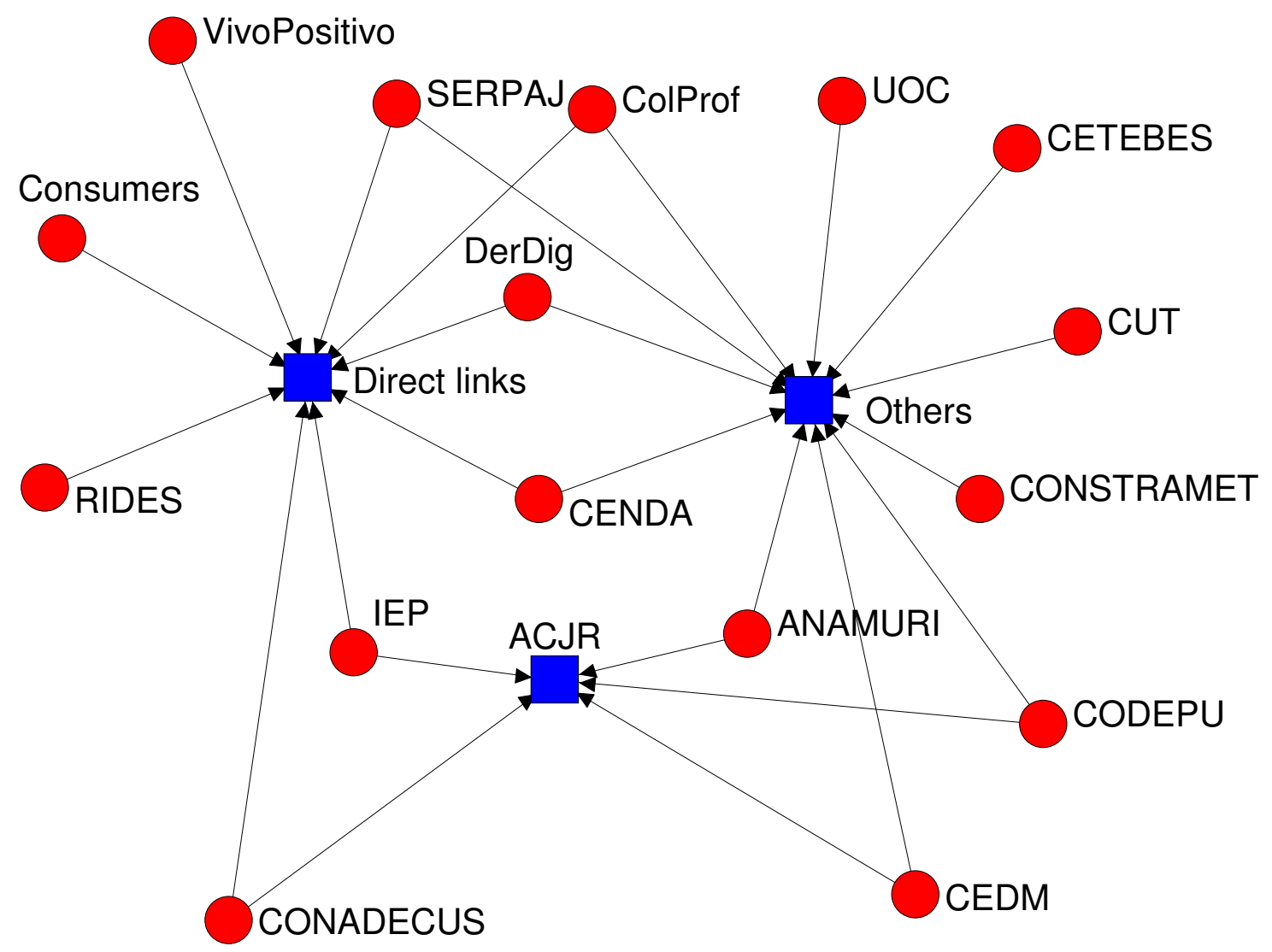

- Civil Society Organisations $\square$ Trajectories

Source: Interviews with members of civil society organisations (see Appendix I).

\footnotetext{
${ }^{24}$ Anonymous interview, Mexico City, August 2005.
} 
In part, these answers explain why, in the case of the Aliança Chilena por um Comércio Justo e Responsável (ACJR - Chilean Alliance for Fair and Responsible Trade), after a long and contentious internal debate, it was decided to end the alliance as a coalition of organisations and transform it, under the same name, into a single NGO. It thus sought to resolve the questions raised about the legitimacy of its members to represent a broader group of actors and to mediate with partners in other countries. As an NGO composed of a small number of individuals rather than a group of organisations with their own heterogeneous agendas, the internal decision-making process is naturally simplified and its autonomy to defend positions is increased. However, at least until 2006, the ACJR was still the national chapter of the Hemispheric Social Alliance. The absence of a Chilean national chapter that might serve as a broad space for harmonising positions on trade agreements presents an unresolved challenge for the HSA, which aims to be an open platform for creating consensus.

In the case of the Mexican Action Network on Free Trade (RMALC), the possibility of following the same path as the ACJR was proposed, but its members made the decision to attempt to break the vicious circle of lack of participation and the crisis of legitimacy by restructuring the organisation, seeking to democratise its decision-making mechanisms and make it more transparent. Whilst in Mexico the weakening of the mediating function of the RMALC is both the cause and consequence of increased links, in Chile the tendency is for the ACJR to be replaced by other mediators with a segmented view of trade agreements.

Although the HSA national chapter in the United States (ART - Alliance for Responsible Trade) has not had to face such a serious crisis as the Mexican and Chilean coalitions, its role as a mediator between national and transnational levels in matters concerning trade has also been questioned. This is the result both of the creation of direct links between organisations and dissatisfaction with the way the coalition functions. Various civil society organisations have complained, since the NAFTA negotiations, that they are ignored by the more powerful organisations (Grassroots Global Justice, 2005). In part, this is a matter of availability of resources to enable local organisations to participate in events that are typically held in the capitals. $^{25}$

\footnotetext{
${ }^{25}$ For example, at one point the Alliance for Responsible Trade hired a "grassroots coordinator," commissioned to open up dialogue with local organisations, but the post was abolished due to lack of funds. Interview with Karen Hansen-Kuhn, ART Secretariat, Washington D.C., September 2005.
} 


\section{CHART 3 - TRAJECTORIES USED BY ORGANISATIONS IN THE UNITED STATES TO MAKE CONTACT WITH PARTNERS IN MEXICO}

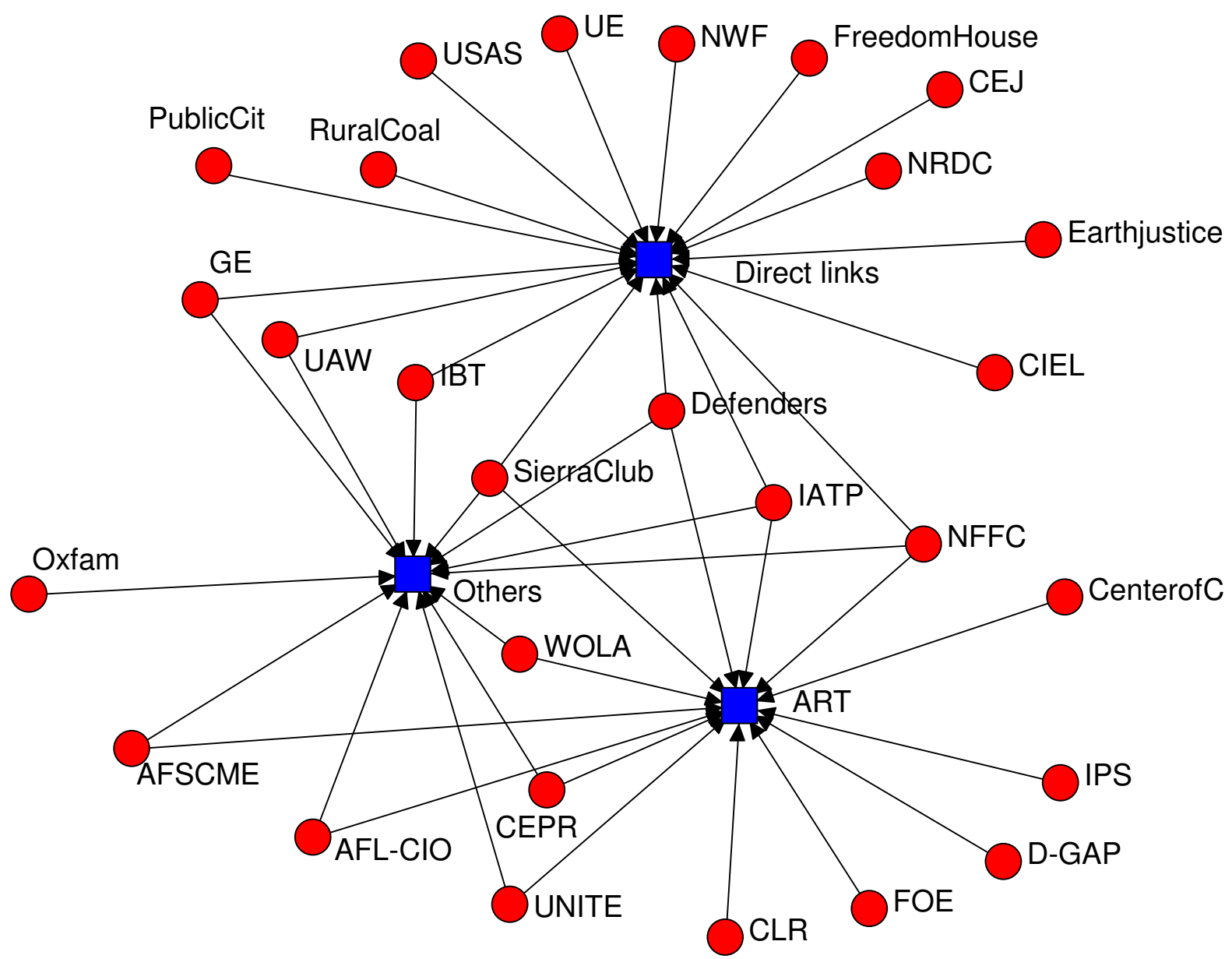

- Civil Society Organisations $\square$ Trajectories

Source: Interviews with members of civil society organisations (see Appendix I).

However, this explanation based on a lack of resources is not sufficient in itself. It is also, essentially, a matter of power relations, of who has the capacity to define objectives and strategies. One document produced by the U.S. organisation Grassroots Global Justice, which unites various local social organisations and movements, makes this clear:

Some of our challenges arise from disagreements about who should drive the strategies and tactics of a campaign - the DC organizations that are counting votes on Capitol Hill or the grassroots organizations [...].grassroots organizations should then be given the resources and political space to assess what are the best strategies and tactics to move their elected officials. This has not been the case [...]. (Grassroots Global Justice, 2005)

The Brazilian civil society organisations entered the debates on free trade agreements much later than their partners in the other three countries, and the HSA national chapter, 
the Rede Brasileira pela Integração dos Povos (REBRIP - Brazilian Network for the Integration of Peoples), was only created in $2001 .^{26}$ The founders of the REBRIP tried to avoid the problems faced by other coalitions by promoting a structure with more channels for the participation of civil society organisations. The creation of thematic working groups has been important in ensuring the participation of some of the main actors. For example, the Agriculture Working Group brings together organisations that would normally have difficulties in working together (such as the MST and the CONTAG, which work with international NGOs such as Oxfam and Action Aid). Members of the REBRIP have also sought to prevent power imbalances and tensions amongst NGOs and grassroots movements from creating irreconcilable conflicts. As one CUT participant explains, it is not easy to find sustainable balances:

There is the risk of REBRIP turning into an NGO, given the power of the NGOs, but this depends a great deal on the participation of the social movements. For example, if CUT participates on the basis of a low profile, there is a greater risk of an NGO profile; if it adopts a very strong profile, the alliance implodes. ${ }^{27}$

Even though the Brazilian national chapter of the HSA is currently the most active of those in the four countries, it does not bring together all the critics of trade agreements in the country and, in addition, does not operate as the sole mediator between national and international levels. When asked how they would make contact with U.S. organisations in case an FTAA event was to be held in the United States, few of those interviewed (only four) said that they would make direct contact with North-American organisations and six said they would use the domestic coalitions (see Chart 4). However, only two of the six would use the REBRIP as the sole mediator. The other four would contact allies in the United States via the national chapter of the Campaign against the FTAA. Similar results were obtained when the question referred to finding allies in Chile or in Mexico, suggesting that, as in other countries, the idea of domestic coalitions as sole mediators has been rejected. In the case of Brazil, the difference is that there is a greater tendency to use other routes to supplement, rather than substitute, the role of coalitions as mediators.

\footnotetext{
${ }^{26}$ Interview with Fátima Mello, REBRIP, Rio de Janeiro, March 2005.

${ }^{27}$ Interview with one CUT member, São Paulo, May 2005.
} 


\section{CHART 4 - TRAJECTORIES USED BY ORGANISATIONS IN BRAZIL TO MAKE CONTACT WITH PARTNERS IN THE UNITED STATES}

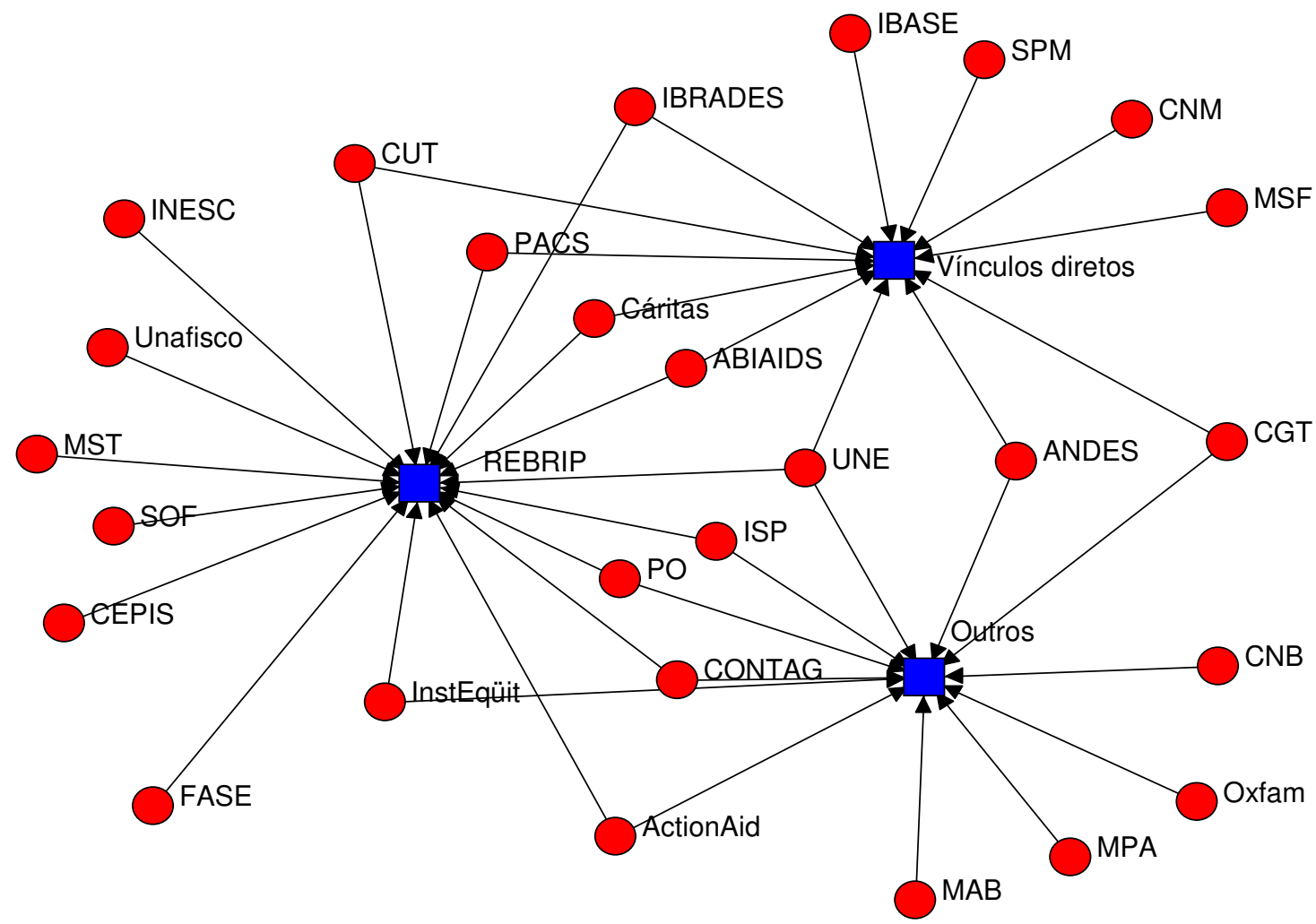

- Civil Society Organisations $\quad \square$ Trajectories

Source: Interviews with members of civil society organisations (see Appendix I).

\section{Conclusion}

Never since the 1990s have conditions been so favourable for collaboration between civil society actors in the Americas, thanks to the end of the Cold War, the transitions to democracy in Latin America and the new agenda for negotiations at hemispheric level. Nowadays there is North-South and South-South dialogue and collaboration that would have been unimaginable twenty years ago. Yet, it is not possible to speak of a "global" or "hemispheric" civil society. Transnational actions are still restricted to a relatively small number of organisations, which are the ones that attend international events and control a large part of the contacts with allies in other countries, resources and access to information. In addition, agreements between actors in different countries and sectors are difficult to build and are often fragile in the face of various domestic pressures and the specific agendas of each organisation. 
Although this article does not support the most optimistic versions of the emergence of open and horizontal spaces for civil society participation, the research indicates some important and innovative trends. Firstly, there is an increase in the number and variety of links between CSOs from the point of view of types of participating organisations and their geographical origins. It is no longer possible to analyse the formation of trade coalitions on the basis of a polarisation between protectionists and "free-traders," with clear and fixed preferences. This polarisation does not reflect the heterogeneity of the actors that take part in debates on trade policies, nor the dynamics of their interaction.

Secondly, new forms of organisation have been created, such as the Hemispheric Social Alliance, supported by organisations that vary from very small NGOs to organisations with millions of members, in order to provide new responses to the old problems of coordination. The literature on transnationalism has taught us a great deal about campaigns and events but offers relatively few clues as to how these new forms of organisation relate to already existing ones. Efforts to construct alliances around trade show how important it is to adopt a more long-term view that enables us to understand the dilemmas and obstacles facing these attempts to build transnational coalitions.

Despite the differences between the four countries studied, there are common challenges. One general and still unresolved issue is how to ensure the participation of local organisations, especially those with limited budgets. Although this problem has not been ignored by participants, none of the four countries have found good solutions for it. It is a problem common to collective action in general, but becomes even more important in the case of collective transnational action. A second question concerns the impact of the trend towards the weakening of the role of domestic trade coalitions as mediators between organisations in the various countries. This trend jeopardises the entire coordination and representation structure put into place by the Hemispheric Social Alliance. The variety of trajectories used by actors is both an indication of the vitality of the field of collective action and evidence of a lack of consensus on how this field should (or should not) be institutionalised.

Translated by Sheena Caldwell

Revised by Teresa Tavares 


\section{References}

Anner, Mark; Evans; Peter (2004), “Building Bridges Across a Double Divide: Alliances between US and Latin American Labour and NGOs," Development in Practice, 14(1 \& 2), 34-47.

Bhagwati, Jagdish (1995), "U.S. Trade Policy: The infatuation with Free Trade Areas," in J. Baghwati; Anne Krueger (eds.), The Dangerous Drift to Preferential Trade Agreements. Washington: The AEI Press, 1-18.

Castells, Manuel (2000), "Materials for an Exploratory Theory of the Network Society," British Journal of Sociology, 51(1), 5-24.

Clemens, Elisabeth S. (2005), "Two Kinds of Stuff: The current encounter of social movements and organizations," in Gerald F. Davis et al. (eds.), Social Movements and Organization Theory. Cambridge: Cambridge University Press, 351-65.

Foster, John (2005), "The Trinational Alliance against NAFTA: Sinews of solidarity," in Joe Bandy \& Jackie Smith (eds.), Coalitions Across Borders: Transnational Protest and the Neoliberal Order. Lanham: Rowman \& Littlefield Publishers, 209-229.

Fox, Jonathan (2002), "Lessons from Mexico-U.S. Civil Society Coalitions," in David Brooks \& J. Fox (eds.), Cross-Border Dialogues: U.S.-Mexico Social Movement Networking. San Diego: Center for U.S.-Mexican Studies at the University of California, 341-418.

Freeman, Linton C. (2004), The Development of Social Network Analysis: A Study in the Sociology of Science. Vancouver: Empirical Press.

Grassroots Global Justice (2005), Briefing Paper for Lessons of Trade Campaigns Meeting. Washington D.C.

Herkenrath, Mark (2006), "Unity and Diversity in Transnational Social Movement Networks - A case study on the Hemispheric Campaign against the FTAA." Paper presented at the International Studies Association Annual Convention, San Diego, CA.

Keck, Margaret; Sikkink, Kathryn (1998), Activists Beyond Borders: Advocacy Networks in International Politics. Ithaca/London: Cornell University Press.

Koo, Jah-Hon (2001), "Maintaining an International Social Movement Coalition: The case of the Hemispheric Social Alliance." Master's thesis, School of Social Work, McGill University, Montreal.

Korzeniewicz, Roberto P.; Smith, William C. (2003a), Mapping Regional Civil Society Networks in Latin America, Report for the Ford Foundation.

Korzeniewicz, Roberto P.; William C. Smith (2003b), "Redes transnacionales de la sociedad civil: entre la protesta y la colaboración," in Diana Tussie \& Mercedes Botto (eds.), El ALCA y las Cumbres de las Américas: una nueva relación público-privada? Buenos Aires: Editorial Biblos \& FLACSO/Argentina, 47-74.

Massicotte, Marie-Josee (2003), “'Local' Organizing and 'Global' Struggles: Coalition-building for social justice in the Americas," in Gordon Laxer \& Sandra Halperin (eds.), Global Civil Society and its Limits. Houndmills, Basingstoke: Palgrave Macmillan, 105-125.

Melucci, Alberto (1996), Challenging Codes: Collective Action in the Information Age. Cambridge: Cambridge University Press.

Mische, Ann (2003), "Cross-talk in Movements: Reconceiving the Culture-Network Link," in Mario Diani \& Doug McAdam (eds.), Social Movements and Networks: Relational Approaches to Collective Action. Oxford: Oxford University Press, 258-280. 
Mische, Ann; White, Harrison (1998), "Between Conversation and Situation: Public switching dynamics across network domains," Social Research, 65(3) 697-724.

Powell, Walter W. (1990), "Neither Market nor Hierarchy: Network forms of organization," Research in Organizational Behavior, 12, 295-336.

von Bülow, Marisa (2009), "Networks of Trade Protest in the Americas: Toward a new labor internationalism?" Latin American Politics and Society, 51(2), 1-28.

von Bülow, Marisa (2010), Building Transnational Networks: Civil Society and the Politics of Trade in the Americas. Cambridge: Cambridge University Press. 


\section{APPENDIX 1 \\ CIVIL SOCIETY ORGANISATIONS CITED IN CHARTS}

\section{A. In Brazil:}

Associação Brasileira Interdisciplinar de Aids (ABIAIDS)

Associação Nacional dos Docentes em Entidades de Ensino Superior (ANDES)

Action Aid Brasil

Cáritas Brasileira

Central Única dos Trabalhadores (CUT)

Centro de Educação Popular - Instituto Sedes Sapientiae (CEPIS)

Confederação Geral dos Trabalhadores (CGT)

Confederação Nacional dos Bancários (CNB)

Confederação Nacional dos Metalúrgicos (CNM)

Confederação Nacional dos Trabalhadores em Agricultura (CONTAG)

Força Sindical

Instituto Brasileiro de Análises Sociais e Econômicas (IBASE)

Instituto Brasileiro de Desenvolvimento (IBRADES)

Instituto de Estudos Sócio-Econômicos (INESC)

Instituto Eqüit

Internacional do Serviço Público (ISP)

Médicos Sem Fronteiras (MSF)

Movimento dos Atingidos por Barragens (MAB)

Movimento dos Pequenos Agricultores (MPA)

Movimento dos Trabalhadores Rurais Sem-Terra (MST)

Oxfam Great Britain - Brazil Program

Pastoral Operária (PO)

Políticas Alternativas para o Cone Sul (PACS)

Sempre-Viva Organização Feminista (SOF)

Serviço Pastoral dos Migrantes (SPM)

União Nacional dos Estudantes (UNE)

Unafisco

\section{B. In Chile:}

Alianza Chilena por un Comercio Justo y Responsable (ACJR)

Asociación Nacional de Mujeres Rurales e Indígenas (ANAMURI)

Centro Ecuménico Diego de Medellín (CEDM)

Centro de Estudios Nacionales de Desarrollo Alternativo (CENDA)

Confederación Trabajadores Bancarios (CETEBES)

Comité de Defensa de los Derechos del Pueblo (CODEPU)

Corporación Nacional de Consumidores y Usuarios (CONADECU)

Confederación de los Trabajadores Metalúrgicos (CONSTRAMET)

Central Única de los Trabajadores (CUT)

Colegio de Profesores Consumers International - Chile Derechos Digitales

Instituto de Ecología Política (IEP)

Programa de Economía del Trabajo (PET)

Recursos e Investigación para el Desarrollo Sustentable (RIDES)

Servicio Paz y Justicia (SERPAJ)

Unidad Obrero Campesina (UOC) Vivo Positivo

\section{In Mexico:}

Asociación Nacional de Empresas Comercializadoras de Productores del Campo (ANEC)

Central Independiente de Obreros Agrícolas y Campesinos (CIOAC)

Centro de Análisis Político e Investigaciones Sociales y Económicas (CAPISE) 
Centro de Derechos Humanos Miguel Agustín Pro Juárez (Centro Pro)

Centro de Estudios para el Cambio en el Campo Mexicano (CECCAM)

Centro de Estudios Ecuménicos (CEE)

Centro de Investigaciones Económicas y Políticas de Acción Comunitaria (CIEPAC)

Centro de Investigación Laboral y Asesoría Sindical (CILAS)

Centro Mexicano de Derecho Ambiental (CEMDA)

Centro Nacional de Comunicación Social (CENCOS)

Confederación de Trabajadores de México (CTM)

Consejo Mexicano para el Desarrollo Sustentable (COMIEDES)

Consejo Nacional de Industriales Ecologistas (CONIECO)

Coordinadora Nacional de Organizaciones Cafetaleras (CNOC)

DECA Equipo Pueblo

Frente Auténtico del Trabajo (FAT)

Frente Democrático Campesino de Chihuahua (FDC)

Fundación Heinrich Böll (FHBoll)

Grupo de Estudios Ambientales (GEA)

Movimiento Ciudadano por la Democracia (MCD)

Mujeres para el Diálogo

Oxfam International/Mexico

Servicio y Asesoría para la Paz (SERAPAZ)

Sindicato Mexicano de Electricistas (SME)

Sindicato de Telefonistas de la República Mexicana (STRM)

Unión Nacional de Organizaciones Regionales Campesinas Autónomas (UNORCA)

D. In the United States:

American Federation of Labor-Congress of Industrial Organizations (AFL-CIO)

American Federation of State, County and Municipal Employees (AFSCME)

Campaign for Labor Rights (CLR)

Center for Economic Justice (CEJ)

Center for International Environmental Law (CIEL)

Center of Concern

Defenders of Wildlife

The Development Group for Alternative Policies (D-GAP)

Earthjustice

Freedom House

Friends of the Earth (FOE)

Global Exchange (GE)

Institute for Agricultural and Trade Policy (IATP)

Institute for Policy Studies (IPS)

International Brotherhood of Teamsters (IBT)

National Family Farm Coalition (NFFC)

National Resources Defense Council (NRDC)

National Wildlife Federation (NWF)

Oxfam America

Public Citizen

Rural Coalition

Sierra Club

Union of Needletrades, Industrial and Textile Employees (UNITE)

United Auto Workers (UAW)

United Electrical, Radio and Machine Workers (UE)

United Students Against Sweatshops (USAS)

Washington Office on Latin America (WOLA) 